\title{
PROBLEMS OF TRANSLATION OF ENGLISH ANNOUNCEMENT TEXTS
}

Y. Kats, PhD in Philology, Associate Professor, https://orcid.org/0000-0003-3230-6066

O. Shmatukha, Student

Sumy State University,

2, Rymskogo-Korsakova St., Sumy, 40007, Ukraine

E-mail: juliakatz@ukr.net; alshmatukha26@yandex.ru

The article deals with the peculiarities of the problems of translation of English announcement texts. The paper is aimed at the general tendency to researches of pragmatical and communicative characteristics of the language phenomena and also the fact that insufficiently studied there is an interrelation between pragmatics of texts, conditions of their functioning, the choice of language means and existence of a large amount of difficulties at the translation of English announcement texts

Keywords: announcement texts, decoding, problems of translation, codding, primary text, editing process.

https://doi.org/10.21272/Ftrk.2018.10(3)-06

Advertisements form a fast growing industry in modern societies. In the past fifty years or so advertisements have become an inseparable part of consumers' lives. Advertising exists in various market systems and the way it affects the receivers varies from system to system. However, it does influence society to behave in a certain way. The past few decades have witnessed an increased demand for the translation of English announcement texts because most products and services available in different countries are imported from American and countries which use English as the language of commerce. In the process of translating English announcement texts, the culture of the people will have an impact on the way the translation is perceived [2].

Announcement texts have a particularly complex structure which requires special attention to both the text's macro-structure (medium) and its micro-structure (i.e. words, phrases and sentences). Translating announcement texts is not an easy task for they are a microcosm of various prosodic, pragmatic, syntactic and textual elements and rather difficult when encountered in translation. Contemporary translated English announcement texts how that many of these advertisements are very much bound to their originals. As a result, the translations are clearly texts of foreign origin which negatively influence consumers 'understanding of the messages conveyed. Consumers, in different cases, frown at English texts transliterated because they include foreign textual elements. These foreign textual elements, which form part of culture-specific concepts, phrases, logos and terms, are translated by means of strategies such as loan words, transliteration and direct translation and dominate a great part of the translated texts. Direct translation maintains the textual-linguistic structure of the source text and also uses many loan words. Direct translation strategies are not acceptable because they retain the source text elements in the translation [5, p. 224]. The purpose of transliteration is to write a language in its customary orthography, using the exact same orthographical letters, but also using carefully substituted orthographical symbols. Although it is possible to use transliteration for English words, it does not satisfy the requirements of non-English speakers who cannot guess their meanings. So, translating English announcement texts requires careful consideration of available strategies. This will retain the original impact of the source text on the target market and in the translated target text.

(C) Y. Kats, O. Shmatukha, 2018 
It became clear that the role played by selected translation strategies to deliver the message in announcement texts to target readers requires special attention. It also became obvious that the current translation strategies that are used to translate English culturespecific terms, phrases, logos and concepts repeatedly affect the rate of sales of consumer goods as they fail to generate the proper message. In this regard, it is pointed out that previous research on this subject was conducted among different language pairs, where the resulting strategies were categorized in a traditional and broad manner, e.g. nontranslation, word-for-word translation and literal translation.

One of the most difficult problems regarding advertisement translation is the translation of logos. The current trend in advertising is to use emotive situations which transcend cultural barriers in international advertising campaigns. A translator has to look for equivalents in terms of relevance in the target language and exercise discretion by substituting certain elements in a text. Even with all the apparent cultural hurdles, a translator can create equivalence by the judicious use of resources. Most translations are intended to serve, however imperfectly, as a substitute for the original, making it available to people who cannot read the language in which it was written. This imposes a heavy responsibility on the translator. One should be familiar with one's own culture and be aware of the source-language culture before attempting to build any bridge between them. The role of the translator is to facilitate the transfer of message, meaning and cultural elements from one language to another.

Translation is, of course, a rewriting of an original text. Rewritings can introduce new concepts, new genres, new devices and the history of translation is the history also of literary innovation, of the shaping power of one culture upon another. But rewriting can also repress innovation, distort and contain, and in an age of ever increasing manipulation of all kinds, the study of the manipulative processes of literature as exemplified by translation can help us toward a greater awareness of the world in which we live.

The announcement text can be characterized as a conceptual model of the reflection of a communicative situation that develops between the three participants (the producer of the original text, the producer of the announcement text, the recipient of the announcement text) $[4$, p. 167]. From the cognitive point of view, the announcement text contains two conceptual kernels that are characterized by a different communicative orientation. The first kernel is that something is available and constitutes some information and it is directed from the original text to the announcement text and implements the informative function [6, p. 45]. The second kernel is that something will be useful for someone and it is directed from the announcement text to the recipient and is realized through the advertising function of the announcement text [1, p. 165]. Example:

Cutting Edge is a multi-level English course for adults and young adults. It combines rich international content, comprehensive grammar, and real-life functional language within a clear, easy-to-teach structure [2].

The first kernel in the example "Cutting Edge is a multi-level English course" provides brief information about the book, the second one - "for adults and young adults" emphasizes who the book is intended for. Next is a description of its characteristics.

Thus, the announcement text is an information model and is aimed at preparing the recipient for his (primary) perception. The main pragmatic task of the announcement text is the presentation of information about the announcement text, therefore, the functional load the announcement text and distributed between the information-incarnating and advertising functions [5, p. 224]. All these features of the ad text must necessarily be retained during translation. Example:

Cutting Edge - ие багаторівневий курс англійської мови для дорослих та молоді. Він поєднує в собі наявність інформації, цікавої для представників всіх національностей, повний об'єм граматики та приклади повсякденної розмовної мови, представленої в зрозумілій, легкій для сприйняття формі.

The primary text is an obligatory element of the conceptual structure of the announcement text, since the implementation of the announcement text is the provision of 
information about the primary text, which occurs by providing the presentation object (primary text) with a more detailed description. The first place is the peculiarities of the structure and content of the book that is the subject of presentations [1, 167]. Example:

Cutting Edge includes these additional key features:

- High-frequency, useful vocabulary

- Regular, well-structured speaking tasks

- Unique Mini-dictionary [2].

The announcement text often has an addressee whose explicit implementation is carried out through the use of a person pronoun you:

One of those long rich, full narrative novels of Howard Spring. You move and live and think with his large assortment of characters [2].

or by the list of admissible recipients of the text [1, p. 167]:

With a discovery approach to grammar and upfront focus on vocabulary, Opportunities ensures the most effective language for teenagers [3].

Consequently, there are certain peculiarities that need to be taken into account when writing promotional texts. The basic requirement for announcement text is the maximum of information and a minimum of words. The text should be written easy to read in the font, in large letters, so that the reader did not have to strain his eyes. The language must be bright and understandable [7, p. 184]:

The announcement texts do not contain such a traditional form of representation of the addressee as a system of pronoun forms of the first person (I, we) [8, p. 240]. Realization of modality in announcement texts is carried out with the help of impersonal sentences. The announcement text, as the secondary type of text contains information about the author of the original text, which creates a positive attitude to the book, gives him confidence. The announcement text uses the words of emotional and rational assessment.

The communicative situation of the announcement texts develops between the three actants: the producer of the original text, the producer of the announcement text and the recipient of the announcement text [1, p. 167]. The announcement text is the preparation of the reader for the perception of the original text. It provides information on the original text, its author, it is determined for whom it is intended.

Translation of the announcement texts from one language to another is a complicated, responsible process that has many difficulties. Translation as a term has a polysemantic nature, its most widespread and mostly generalizing meaning associated with the process of passing the value / content of the word, group of words, sentence or excerpt from the language of the original to the language of translation [9, p. 144]. The term "translation" can be defined as follows: the replacement of text material in one language (the language of the original) is equivalent to the text material of another language (language of translation). The main purpose of any translation is to achieve adequacy. An adequate translation can be defined as a translation, which provides the pragmatic tasks of the translation act to the maximum possible level for achieving this goal of equivalence.

In the process of translation, regardless of its form (oral or written), we can distinguish the following basic steps [10, p. 319]:

1. Decoding or understanding (reading, listening) the text in the source language

2. Translation

3. Codding (recording, voice over) of the received text in the language of translation.

But also the text editing process, which is defined as a view (in other words, analysis, control) and correction of messages, is also very important. According to most researchers, the subject of editing is to bring the object of editing in line with the rules in force at certain times and in a specific society, as well as its creative optimization, whose purpose is to obtain a given social effect. The process of editing is to verify the information in order to improve or correct its structure, content, compliance, completeness, logical sequence, presentation methods. Since the editor is facing a different task, his work must be organized and systematized [11, p. 256]. 
For many translators, the text of a foreign language serves only as a means to understand the idea of the subject matter, but the text itself is often rewritten in the language of the consumer's country, taking into account the peculiarities of its national specificity. In those cases where the exact translation is inappropriate, the translator uses approximate phrases that must take into account traditional ethnic, national and social peculiarities, and stereotypes of the behavior of a particular audience. Certain difficulties arise in the translation of individual words, sentences, if for decoding the information contained in them; one must resort to extra-linguistic factors: background knowledge, knowledge of special terms, abbreviations, etc. [11, p. 656].

Another problem for an interpreter may be the translation of content of their proper names. Such names perform in a speech function as a sign that names, and a sign, that means, because they not only point to the object, but also characterize it usually from an ironic or satirical point of view. The translator must find such content for the internal form of the name, which would adequately characterize the same with the pronounced original quality of the character and faithfully reflect the author's attitude towards it.

\section{ПРОБЛЕМИ ПЕРЕКЛАДУ АНГЛОМОВНИХ ТЕКСТІВ-АНОНСІВ}

ю. В. Кац, канд. філол. наук, дочент,

о. I. Шматуха, студентка

Сумський державний університет

вул. Римського-Корсакова, 2, Суми, 40007, Украӥна

Email: juliakatz@ukr.net; alshmatukha26@yandex.ru

Стаття присвячена дослідженню проблем перекладу англомовних текстів-анонсів. Основною метою дослідження є загальна тенденція до аналізу прагматико-комунікативних характеристик мовних явищ. Мотивачією написання статті є те, шо недостатньо вивченим залишається взаємозв'язок між прагматикою текстів, умовами їх функиіонування, з одного боку, і вибором мовних засобів, з іншого. Це породжує наявність великої кількості труднощів при перекладі англомовних текстів-анонсів. Стаття засвідчує випадки багатозначності слів і описує роль контексту в перекладі англомовних текстів-анонсів. В статті розглядаються лінгвостилістичні особливості перекладу англомовних текстів українською мовою. Основними етапами дослідження $\epsilon$ пошуково-ознайомлювальний, який полягає в доборі бібліографії, ознайомленні з літературою, складанні картотеки; аналітичний, який полягає в тому, щзо в роботі здійснюється критичний огляд літератури, формується власна кониепиія дослідження класифікується матеріал; етап систематизаиї необхідного матеріалу та його опис. Практичне використання результатів дослідження полягає в тому, щзо отримані дані можна застосувати при розв'язанні практичних завдань перекладу. При перекладі англомовних текстів-анонсів необхідно враховувати не лише мету, характер потенційного читача, але й особливості тексту оригіналу, культурні й індивідуальні можливості мови та інші екстралінгвістичні фактори. Перспективи вбачаємо у аналізі англомовних текстів-анонсів для перекладу та створення текстів, а також детальний розгляд їхньої класифікації для подальшої роботи у галузі перекладу англомовних текстів-анонсів. За результатами дослідження можна зробити висновок, що існує необхідність у подальшому вивченні англомовних текстів-анонсів та створенні нових підходів до його перекладу та подолання проблем перекладу.

Ключові слова: тексти-анонси, декодування, проблеми перекладу, кодування, первинний текст процес редагування.

\section{ПРОБЛЕМЫ ПЕРЕВОДА АНГЛОЯЗЫЧНЫХ ТЕКСТОВ-АНОНСОВ}

Ю. В. Кац, канд. филол. наук, дочент;

А. И. Шматуха, студентка

Сумский государственный университет,

ул. Римского-Корсакова, 2, Сумы, 40007, Украина

Email: juliakatz@ukr.net; alshmatukha26@yandex.ru

Статья посвящена исследованию проблем перевода англоязычных текстов-анонсов. Основной целью исследования является общая тендениия $\kappa$ исследованиям прагматическо-коммуникативных характеристик языковых явлений, а также тем, что недостаточно изученной остается взаимосвязь между прагматикой текстов, условиями их функционирования, с одной стороны, и выбором языковых средств, с другой; наличием большого количества трудностей при переводе англоязычных текстованонсов.

Ключевые слова: тексты-анонсы, декодирование, проблемы перевода, кодирование, первоначальный текст, прочесс редактирования. 


\section{REFERENCES}

1. Sokolova, I. V. Features of realization of the conceptual space of announcement texts in the aspect of recurrence representation of concepts // Sumy State University.

2. Sarah Cunningham, Peter Moor, Cutting Edge, Intermediate, Student's Book.

3. Michael Harris, David Mower, Opportunities, Upper Intermediate, Student's Book.

4. Komissarov, V. N. Linguistics of Translation. - K. : International relations, $1980-167$ p.

5. Moiseev, V. A. Public Relations, 2007. - 224 p.

6. Sukhenko, K. M. Lexical translation problems. - K. : Publishing House of Kyiv Taras Shevchenko National University, 1972. -45 p.

7. Alekseeva, I. S. Text and translation. Questions of theory: [monograph] / Irina Sergeevna Alekseeva. - M. : Intern. relations, 2008. $-184 \mathrm{p}$.

8. Barkhudarov, L. S. Language and Translation (Questions of General and Particular Translation Theory) / Barkhudarov, L. S. - Moscow : International Relations, 2008. - 240 p.

9. Galperin, I. R. Text as an object of linguistic research. - M. $-2009 .-144$ p.

10. Discourse as a Cognitive-Communicative Phenomenon: 200th Anniversary of Kharkiv National University named after Karazin N. V. is devoted to / [L. R. Bezugla, E. V. Bondarenko, P. M. Donets, A. P. Martynyuk., O. I. Morozova.]; V. N. Karazin Kharkiv National University. - Kh. : Constant, 2005. - 356 pp. - The bibliographer: p. 319-354.

11. Lilova, A. Introduction to the general theory of translation / Lilova, A. - M. : Higher school, 1995. - 256 p.

12. Pocheptsov, G. G. Theory of Communication / Pocheptsov, G. G. - M. : Refl-Book, K.: Vackler, 2001. $656 \mathrm{p}$.

\section{СПИСОК ВИКОРИСТАНИХ ДЖЕРЕЛ}

1. Соколова І. В. Особливості реалізації концептуального простору текстів-анонсів в аспекті рекурентної представленості концептів// Вісник СумДУ, Серія Філол. науки. - 2002. - № 4'(37). - С. 164-167.

2. Sarah Cunningham, Peter Moor, Cutting Edge, Intermediate, Student's Book.

3. Michael Harris, David Mower, Opportunities, Upper Intermediate, Student's Book.

4. Комісаров В. Н., Лінгвістика перекладу. - К. : Міжнародні відносини, 1980. - 167 с.

5. Мойсеєв В. А. Паблік рілейшинз: Навчальний посібник. - К. : Академвидав, 2007. - 224 с.

6. Сухенко К. М., Лексичні проблеми перекладу. - К. : Видавництво Київського Національного Універсітету ім. Тараса Шевченка, 1972. - 45 с.

7. Алексеева И. С. Текст и перевод. Вопросы теории : [монография] / Ирина Сергеевна Алексеева. - М. : Междунар. отношения, 2008. - 184 с.

8. Бархударов Л. С. Язык и перевод (Вопросы общей и частной теории перевода) / Л. С. Бархударов. М. : Международные отношения, 2008. - 240 с.

9. Гальперин И. Р. Текст как объект лингвистического исследования / Либроком. - М. - 2009. -144 с

10. Дискурс як когнітивно-комунікативний феномен: 200-річчю Харківського національного університету імені В.Н.Каразіна присвячується / [Л. Р. Безугла, Є.В.Бондаренко, П. М. Донець, А. П. Мартинюк, О. І. Морозова]; Харківський національний ун-т ім. В. Н. Каразіна. - Х. : Константа, 2005. - 356 с. Бібліогр.: с. 319-354.

11. Лилова А. Введение в общую теорию перевода / А. Лилова. - М. : Высшая школа, 1995. - 256 с

12. Почепцов Г. Г. Теория коммуникации / Г. Г. Почепцов. - М. : Рефл-бук, К.: Ваклер, 2001. - 656 с.

Received: 2 March, 2018 